\title{
Application of mineral admixtures and steel fibers in experimental compositions for
}

\section{reactive powders concrete}

\author{
Aplicação de adições minerais e fỉbras de aço em composições experimentais para concreto de pós \\ reativos
}

Aplicación de adiciones minerales y fibras de acero en composiciones experimentales para hormigón en polvo reactivo

\begin{abstract}
Concrete is a material used in various applications, involving paving, sanitation, infrastructure and superstructure works, dams, bridges, and architectural elements, but for certain applications their physical and mechanical properties are affected by intense degradation agents, motivating the search for artifacts that improve these properties and increase the useful life and durability of matrix materials cement industry. The objective of this work is to clarify the influence of different mix of superplasticizer, steel fibers, water/cement factor, different types of mineral admixtures, besides the type of thermal treatment and method of cylindrical concrete molds of reactive powders, evaluating the resistance to axial compression at the ages of 7 and 14 days. 17 compositions were defined, by mass, for the manufacture of concretes, divided into two stages: the first composed of 10 compositions, and the second by 7 compositions. It was used CP-V ARI cement, sand, metakaolin, silica fume, superplasticizer and kneading water with temperature between 1 and $3^{\circ} \mathrm{C}$. After the conformation of the cylindrical molds of dimensions $5 \times 10 \mathrm{~cm}$ with the aid of a portable immersion vibrator, the specimens were unmolded after 24 hours and received thermal treatment with periods of pre-cure and isotherm that varied according to the defined trait. According to the results obtained, the reduction of the w/c factor and the superplasticizer additive presented higher resistance to compression, however, this reduction in an excessive way impairs the hydration process, implying in the incomplete hydration of all the cement particles, resulting in less resistance. It was observed that the application of thermal treatment and densification by means of layer immersion vibrators acted as essential factors in the increase of the resistances, and that the isotherm time of the composite corroborates the respective increase, until its stabilization, in the temperatures studied.
\end{abstract}

Keywords: UHPC; Mineral admixtures; Heat treatment; Steel fibers.

\section{Resumo}

O concreto é um material utilizado em variadas aplicações, envolvendo obras de pavimentação, saneamento, infraestrutura e superestrutura, barragens, pontes, e elementos de arquitetura, porém para determinadas aplicações, as suas propriedades físicas e mecânicas são acometidas por intensos agentes de degradação, motivando a busca de artifícios que melhorem tais propriedades e eleve a vida útil e durabilidade dos materiais de matriz cimentícia. Como objetivo, este trabalho busca estudar as influências, em diferentes composições, relacionadas ao emprego em diferentes quantidades de aditivo e adições minerais, fibras de aço, fator água/cimento, além do tipo de tratamento térmico e método de adensamento adotado para conformação dos moldes cilíndricos de concreto de pós reativos, avaliando a resistência à compressão axial nas idades de 7 e 14 dias. Foram definidas 17 composições, em massa, para fabricação do material, divididas em duas etapas: a primeira composta por 10 composições, e a segunda por 7 composições. Utilizou-se cimento CP-V ARI, areia, metacaulim, microssílica, aditivo superplastificante e água de amassamento com temperatura entre 1 e $3^{\circ} \mathrm{C}$. Após a conformação dos moldes cilíndricos de dimensões $5 \times 10 \mathrm{~cm}$ com auxílio de vibrador de imersão portátil, os corpos de prova foram receberam tratamento térmico com períodos de précura e de isoterma que variaram de acordo com o traço definido. De acordo com os resultados obtidos, com a redução do fator a/c e respectivo aumento do aditivo obteve-se maiores resistências à compressão, todavia essa redução de 
forma excessiva prejudica o processo de hidratação, implicando na não completa hidratação de todas as partículas de cimento, resultando em menores resistências. Foi observado que a aplicação de tratamento térmico e adensamento por meio de vibrador de imersão em camadas agiram como fatores essenciais no aumento das resistências, e que o tempo de isoterma do compósito corrobora o respectivo aumento, até sua estabilização, nas temperaturas estudadas.

Palavras-chave: CUAD; Adições minerais; Tratamento térmico; Fibras de aço.

\section{Resumen}

El hormigón es un material utilizado en diversas aplicaciones, que involucran pavimentación, saneamiento, obras de infraestructura y superestructura, presas, puentes y elementos arquitectónicos, pero para determinadas aplicaciones, sus propiedades físicas y mecánicas se ven afectadas por agentes de degradación intensos, motivando la búsqueda de artificios que mejoren dichas propiedades y aumenten la vida útil y durabilidad de los materiales de matriz cementosa. Como objetivo, este trabajo busca estudiar las influencias, en diferentes composiciones, relacionadas con el uso en diferentes cantidades de aditivos y adiciones minerales, fibras de acero, factor agua / cemento, además del tipo de tratamiento térmico y método de densidad adoptado para conformar los moldes. Hormigón cilíndrico a partir de polvos reactivos, evaluando la resistencia a la compresión axial a las edades de 7 y 14 días. Se definieron 17 composiciones, en masa, para la fabricación del material, divididas en dos etapas: la primera compuesta por 10 composiciones, y la segunda por 7 composiciones. Se utilizó cemento CP-V ARI, arena, metacaolín, sílice activa, aditivo superplastificante y agua de amasado con temperatura entre 1 y $3^{\circ} \mathrm{C}$. Luego de conformar moldes cilíndricos de dimensiones $5 \times 10 \mathrm{~cm}$ con la ayuda de un vibrador de inmersión portátil, las probetas fueron tratadas térmicamente con períodos de pre-curado e isoterma que variaban según la línea definida. De acuerdo con los resultados obtenidos, con la reducción del factor a/c el respectivo aumento del aditivo, se obtuvieron mayores resistencias a la compresión, sin embargo, esta reducción excesiva perjudica el proceso de hidratación, implicando la hidratación completa de todas las partículas de cemento, lo que resulta en una menor resistencia. Se observó que la aplicación de tratamiento térmico y densificación mediante vibrador de inmersión estratificado actuó como factores esenciales en el aumento de las resistencias, y que el tiempo de isoterma del composite corrobora el respectivo aumento, hasta su estabilización, en las temperaturas estudiadas.

Palabras clave: HUAD; Adiciones minerales; Tratamiento térmico; Fibras de acero.

\section{Introduction}

In view of the technological advances that the civil construction sector is immersed in, measures that can improve and bring benefits to the technical applications developed in each specified case are being increasingly palatable, with plausible solutions based on the needs arising in practice.

Seitenfuss, Lima and Silva (2014) highlight that the High-Performance Concrete (HPC) class consists of the largescale use of products with a cementitious characteristic combined with the low water/cement factor (w/c) adopted in the mixture, in addition to the care regarding the quality control of the materials used and respective application in specific constructions. According to Biz (2001), this approach seeks to configure properties close to the rocks, however with the advantage of being moldable.

The concretes that have a more rigorous character with regard to their technological control, from the characterization of the materials involved, to the manufacture of a composite with properties up to 8 times more potent than conventional concretes, demand highly specialized labor, in addition to state-of-the-art equipment with a favorable structure for the development of products for scale tests with real sampling.

In a higher class of strength and durability, Reactive Powders Concrete (RPC) was created by Richard and Cheyrezy (1995), classified among the ultra-high-performance concretes based on Portland cement that has the best physical and mechanical properties patented to date, used in same applications as conventional concrete or as auxiliary technology. The minimum threshold for compressive strength comprises values of the order of $120 \mathrm{MPa}$ (Dixit, Du \& Pang, 2020), however, in most studies, 150MPa is adopted at 28 days of age (Kang, Hong \& Moon, 2019; Liu, Wei, Zou, Zhou \& Jian, 2020; Sohail, Kahraman, Nuaimi, Gencturk \& Alnahhal, 2021).

The RPC covers several possibilities for the composition of a cement matrix that corroborates high resistance, however it is necessary to articulate experimental programs that facilitate practical application and with satisfactory results. Thus, Vanderlei (2004) demonstrates two aspects of RPC development studied today. The first covers concrete with a compact 
particle size matrix (DSP: Densified System containing ultra-fine Particles), with high applications of silica fume and superplasticizer, use of resistant aggregates and considerable water reduction in the mixture. The second consists in the study of MDF (Macro-Defect Free) polymer paste, with high reach in tensile strengths (150MPa or higher), particularly when aluminous cements are involved in the mixture.

Therefore, RPC was developed as an alternative to the use of HPC, and in certain cases also to steel. In scale, conventional concrete can achieve strengths of up to 60MPa, HPC between 60MPa and 120MPa, and RPC encompasses a range of compressive strength ranging from 200MPa to 800MPa, subdivided into classes of RPC 200 and RPC 800, which depending on the resistance range, new classifications are used, such as the RPC C500.

By eliminating coarse aggregates in the mixture, the tortuosity of the porous network is improved through effective refinement, with no transition zone between aggregate and Portland cement paste, where Tutikian, Isaia \& Helene (2011) claim to increase the skeleton surface granular, banning internal voids or pores adhered to the aggregate surface.

Among the characteristics that RPC incorporates, a premise followed is the formation of a mixture of great homogeneity, which in contrast to conventional concrete characterized as heterogeneous, RPC is homogeneous. This homogenization is characterized due to the exclusion of coarse aggregates, so that the granulometric distribution facilitates a better densification of the transition zone between the fine aggregate and the cementitious paste (Vanderlei, 2004), since the method of packaging the particles provides a composition $100 \%$ shielded.

The mineral admixtures that involve the effective performance of HPC and Ultra-High-Performance Concrete (UHPC) class special concretes provide the improvement of properties in the fresh and hardened state, such as better malleability, self-density, causing, according to Oliveira (2020), the relevant increase in axial compression resistance and durability. Because they have pozzolanic characteristics, that is, they produce secondary hydration compounds (C-S-H), such as cement, when in the presence of calcium hydroxide $(\mathrm{CH})$, one of the cement hydration products "[...] fill the voids large, they refine the structure of the pores and [...] consequently, the permeability of the system is reduced and there is an increase in the mechanical strength and durability of the concrete" (Perim, 2013).

It is noteworthy that even in most works involving high strength materials based on Portland cement, only one mineral admixture is applied, emphasizing the silica fume, other authors propose the action of two admixtures with synergistic action, such as the addition of nanosilica and silica fume adopted by Mallmann (2013), who sought to ascertain the properties of sandfree RPC and with extensive thermal cure, and Rigo (2016), studying mortars for application in concrete with a focus on improvements in mechanical performance. In this study, we opted for the use of metakaolin due to the granulometric similarity in relation to the quartz powder, component of the RPC, and by favoring the chain reaction next to the silica fume.

RPC was created to meet the demands that have been sought since the creation of conventional Portland cement concrete: lower w/c ratio, greater durability, better particle packing, greater resistance, better ductility and toughness, low porosity, better densification of the transition, among others.

Tutikian, Isaia and Helene (2011) explain that the RPC principle is in the foreground associated with the removal of coarse aggregate from the composition, leaving only materials that, from a granulometric and conventional point of view, are similar to mortar, significantly increasing the specific surface that composes the granular skeleton of the composite (Andrade, 2015), incorporating in its composition steel microfibers in cases of structural adaptation, with the exclusive use of steel rebars.

In a simplified way, RPC is understood to mean material whose composition consists basically of powders, where the granulometry of the applied materials does not exceed the value of $2 \mathrm{~mm}$ with a bias of application in structural elements. Vanderlei (2004) clarifies that the material offers great compressive strengths, in addition to being able to effectively resist tensile stresses when metallic fibers are added to its composition.

It is noted by Figueiredo (2011) that "when fibers of appropriate resistance and modulus of elasticity are added and in 
an appropriate content, the concrete ceases to have a markedly fragile character", which ensures less cracking of the composite, ratifying the recommendation for the use in conventional concrete reinforced or not, and serving as a complementary reinforcement to reduce cracking.

Synthesizing the parameters that allow exposing the benefits of applying thermal curing procedures to RPC, Richard and Cheyrezy (1995) emphasize that the thermal treatment substantially accelerates the pozzolanic reactivity during the modification of the microstructure of the hydrates being formed, which remain amorphous at curing temperatures up to $90^{\circ} \mathrm{C}$.

Verifying that the use of mineral admixtures transfers to the final product improvements in terms of better packaging of particles and filling of voids, in the face of this process filled by mixing water, by the hydration products of Portland cement, the application of more than one mineral admixture produces a synergistic effect that confirms greater resistance in a timely manner, which for Rigo (2016) enables the production of concretes with superior structural properties so that they can be applied in usual works. This leads to the generation of low-density C-S-H (Cunha Oliveira, Chagas, Meira, Carneiro \& Melo Neto, 2020), a fundamental hydration product in obtaining high physical-mechanical performance in cementitious matrix products (Pelisser, Gleize \& Mikowski, 2009).

Thus, the objective of this study is to evaluate the mechanical performance of concrete mixtures of reactive powders at 7 and 14 days of age, according to the variation in the quantity of raw materials involved in the study, the method of densification and the applied thermal cure.

\section{Methodology}

\subsection{Materials}

* Cement: The cement belongs to class V, named Portland Cement of High Initial Resistance (CP V-ARI). It provides a high resistance in the early ages, favoring resistances close to 50MPa on the third day of concrete hydration. Vanderlei (2004) used the CP V-ARI SR (Sulfate Resistant). The cement was obtained through a donation from Elizabeth Cimentos - Alhandra-PB Unit.

- Sand: It has Maximum Characteristic Diameter $(\Phi \max )=0,6 \mathrm{~mm}$ and Fineness Module $(\mathrm{FM})=1.468$, classified as very fine aggregate. The sand was purchased in a building material deposit near the IFPB Campus Campina Grande, with density $(\gamma)=2.659 \mathrm{~g} / \mathrm{cm}^{3}$.

* Silica fume: It was possible to obtain the silica fume in the metropolitan region of São Paulo, through a partial donation from Tecnosil S.A. to carry out the tests. It is a highly reactive mineral admixture. It has a specific mass of $470 \mathrm{~kg} / \mathrm{m}^{3}$ and a specific surface close to $18,000 \mathrm{~cm}^{2} / \mathrm{g}$, according to the manufacturer's technical sheet.

* Metakaolin: Material used as an alternative to replace quartz powder. Metakaolin is obtained through the controlled burning of clays with a high kaolinite content, becoming an artificial pozzolan that improves the properties of concrete as a final product. This raw material was obtained through a donation from Maia Macedo Impermeabilizante (João Pessoa-PB). It has a specific mass of $2,330 \mathrm{~kg} / \mathrm{m}^{3}$ and a specific surface of $209,000 \mathrm{~cm}^{2} / \mathrm{g}$, according to the manufacturer's technical sheet.

* Steel Fibers: Dramix ${ }^{\circledR}$ material of the 3D family with a length of 30mm, diameter of $0.62 \mathrm{~mm}$, form factor (1/d) 45 , and Young's modulus of $\pm 210,000 \mathrm{MPa}$ with an average tolerance of $\pm 7.5 \%$. Obtained through a donation from the multinational ArcelorMittal (Belgo Bekaert Arames), one of the only companies in the country that works with fibers of such reduced sizes.

* Additive: Component used to give in the fresh state greater plasticity of the mixture when composed of high content of fines, the additive, classified as superplasticizer, is of the type MasterGlenium ${ }^{\circledR} 51$, of 3rd generation for concrete, manufactured with chemical base in polycarboxylic ether with $\mathrm{pH}$ between 5 and 7 , specific mass between 
$1.067 \mathrm{~g} / \mathrm{cm}^{3}$ and $1.107 \mathrm{~g} / \mathrm{cm}^{3}$, viscosity $<150 \mathrm{cps}$ and solids content between $28.5 \%$ to $31.5 \%$, according to the manufacturer's technical sheet. Obtained through donation from the multinational BASF.

* Mixing Water: Obtained from public supply in the city of Campina Grande-PB, it was collected from the faucet of the Construction Materials laboratory and stored in PET bottles, later conditioned in a minibar, remaining in constant cooling until the time of use, reaching from 1 to $3^{\circ} \mathrm{C}$. The reason for using water at extremely low temperatures is due to the reduction of the hydration heat released by the cement, which, being class $\mathrm{V}$, releases more intensely, and combined with water, the mineral admixtures involved also contribute to this heat of hydration is reduced, improving the curing process of the concrete without high losses of humidity to the environment, guaranteeing the perfect realization of the cure in the first hours.

\subsection{Methods}

Based on the mix developed by Vanderlei (2004), for the experimental study of reactive powders concrete (Table 1), 17 mass compositions were elaborated to evaluate the behavior that each composition tested on the material in the hardened state, divided in two stages of work.

Table 1 - Composition used as support for the new features developed.

\begin{tabular}{l|c|c}
\hline \multicolumn{1}{c|}{ Material } & Mass Ratio (kg) & Consumption (kg/m $\mathbf{m}^{\mathbf{3}}$ \\
\hline Cement & 1 & 874 \\
\hline Sand & 1,101 & 205 \\
\hline Quartz Powder & 0,235 & 215 \\
\hline Silica Fume & 0,246 & 26 \\
\hline Superplasticizer (3\%) & 0,030 & 157 \\
\hline Water (w/c = 0,18) & 0,180 & \\
\hline
\end{tabular}

Source: Vanderlei (2004).

Thus, the 17 compositions were divided into 2 stages, the first composed by 10 initial compositions, and the second by 7 compositions that, based on the results of the first stage, were improved to increase the values obtained at 7 and 4 days, with the increase in steel fibers for only one composition, seeking to investigate the influence, occasionally, in the increase of resistance to axial compression.

Because quartz powder is not available in the study area, metakaolin was used, as it is a material of similar granulometry (\# 325), wishing to produce similar results for the studied ages. In contrast, metakaolin is reactive in the presence of $\mathrm{CH}$, a cement hydration product, which causes an increase in the resistance of the final product due to the material's pozzolanic properties. Thus, the consumption could not be similar to that of the quartz powder adopted by Vanderlei (2004), its quantity being reduced due to the failure to correctly and completely perform the reactions due to its high quantity. For each age of study, depending on the mix, 3 specimens were manufactured.

\subsubsection{First Step}

Table 2 below sets out the compositions determined empirically, for the study of reactive powders concrete. 
Table 2 - Compositions of the first stage of manufacturing the specimens.

\begin{tabular}{|c|c|c|c|c|c|}
\hline \multicolumn{6}{|c|}{ Mixture - $1(H T 1+V 1)$} \\
\hline Cement & Sand & Metakaolin & Silica Fume & Additive SP & $\mathbf{w} / \mathbf{c}$ \\
\hline 1 & 1,040 & 0,267 & 0,287 & 0,035 & 0,505 \\
\hline \multicolumn{6}{|c|}{ Mixture - 2 $(H T 1+V 1)$} \\
\hline Cement & Sand & Metakaolin & Silica Fume & Additive SP & $\mathbf{w} / \mathbf{c}$ \\
\hline 1 & 1,040 & 0,267 & 0,287 & 0,0875 & 0,435 \\
\hline \multicolumn{6}{|c|}{ Mixture - $3(H T 1+V 1)$} \\
\hline Cement & Sand & Metakaolin & Silica Fume & Additive SP & w/c \\
\hline 1 & 1,050 & 0,177 & 0,197 & 0,120 & 0,314 \\
\hline \multicolumn{6}{|c|}{ Mixture - 4 $(H T 1+V 1)$} \\
\hline Cement & Sand & Metakaolin & Silica Fume & Additive SP & $\mathbf{w} / \mathbf{c}$ \\
\hline 1 & 1,050 & 0,157 & 0,197 & 0,115 & 0,314 \\
\hline \multicolumn{6}{|c|}{ Mixture - 5 $(H T l+V l)$} \\
\hline Cement & Sand & Metakaolin & Silica Fume & Additive SP & $\mathbf{w} / \mathbf{c}$ \\
\hline 1 & 1,050 & 0,175 & 0,195 & 0,115 & 0,244 \\
\hline \multicolumn{6}{|c|}{ Mixture - 6 $(H T 1+V 1)$} \\
\hline Cement & Sand & Metakaolin & Silica Fume & Additive SP & $\mathbf{w} / \mathbf{c}$ \\
\hline 1 & 1,050 & 0,177 & 0,197 & 0,120 & 0,266 \\
\hline \multicolumn{6}{|c|}{ Mixture - $7(H T 2+V 2)$} \\
\hline Cement & Sand & Metakaolin & Silica Fume & Additive SP & $\mathbf{w} / \mathbf{c}$ \\
\hline 1 & 1,050 & 0,177 & 0,197 & 0,120 & 0,314 \\
\hline \multicolumn{6}{|c|}{ Mixture - 8 $(H T 2+V 2)$} \\
\hline Cement & Sand & Metakaolin & Silica Fume & Additive SP & $\mathbf{w} / \mathbf{c}$ \\
\hline 1 & 1,050 & 0,177 & 0,197 & 0,120 & 0,290 \\
\hline \multicolumn{6}{|c|}{ Mixture - $9(H T 2+V 2)$} \\
\hline Cement & Sand & Metakaolin & Silica Fume & Additive SP & $\mathbf{w} / \mathbf{c}$ \\
\hline 1 & 1,050 & 0,177 & 0,197 & 0,120 & 0,266 \\
\hline \multicolumn{6}{|c|}{ Mixture - $10(H T 2+V 2)$} \\
\hline Cement & Sand & Metakaolin & Silica Fume & Additive SP & $\mathbf{w} / \mathbf{c}$ \\
\hline 1 & 1,050 & 0,177 & 0,197 & 0,120 & 0,244 \\
\hline
\end{tabular}

Souce: Authors.

As adopted for the first stage, densification and thermal curing procedures were established as the amounts of aggregate, mineral admixtures, additive SP, and w/c factor were modified. The first six were separated for different densification and curing conditions, and the next four were manufactured with an emphasis on improvements in these stages.

In Heat Treatment 1 (HT1), the pre-cure time adopted was 72 hours, with an isotherm of 16 hours at a temperature of $75^{\circ} \mathrm{C}$, and a total heating time of 20 hours (4 hours of temperature increase +16 hours isotherm), and Vibration 1 (V1), which consisted of dividing into 2 layers with 30 seconds of vibration. In Heat Treatment 2 (HT2), the pre-cure time adopted was 32 
hours, with an isotherm of 24 hours at a temperature of $65^{\circ} \mathrm{C}$, and a total heating time of 28 hours (4 hours of temperature rise and 24 hours isotherm), and Vibration 2 (V2), which consisted of dividing into 3 layers with 30 seconds of vibration.

\subsubsection{Second Step}

Table 3 below shows the compositions determined from those in the previous 10, however seeking to maximize the resistive power, reducing mainly the amount of mineral admixtures and the w/c factor, in addition to modifying the curing conditions with different isotherms and a single mix without treatment or vibration, for a final comparison of the efficiency of the procedures.

Table 3 - Compositions of the second stage of manufacturing the specimens.

\begin{tabular}{|c|c|c|c|c|c|}
\hline \multicolumn{6}{|c|}{ Mixture - 11} \\
\hline Cement & Sand & Metakaolin & Silica Fume & Additive SP & w/c \\
\hline 1 & 1,050 & 0,177 & 0,197 & 0,120 & 0,290 \\
\hline \multicolumn{6}{|c|}{ Mixture - 12 $(H T 1+V 1)$} \\
\hline Cement & Sand & Metakaolin & Silica Fume & Additive SP & $\mathbf{w} / \mathbf{c}$ \\
\hline 1 & 1,050 & 0,177 & 0,197 & 0,120 & 0,290 \\
\hline \multicolumn{6}{|c|}{ Mixture - $13(H T 2+V 2)$} \\
\hline Cement & Sand & Metakaolin & Silica Fume & Additive SP & $\mathbf{w} / \mathbf{c}$ \\
\hline 1 & 1,050 & 0,177 & 0,197 & 0,120 & 0,214 \\
\hline \multicolumn{6}{|c|}{ Mixture - $14(H T 3+V 2)$} \\
\hline Cement & Sand & Metakaolin & Silica Fume & Additive SP & $\mathbf{w} / \mathbf{c}$ \\
\hline 1 & 1,050 & 0,070 & 0,120 & 0,085 & 0,214 \\
\hline \multicolumn{6}{|c|}{ Mixture - $15(H T 3+V 2)$} \\
\hline Cement & Sand & Metakaolin & Silica Fume & Additive SP & $\mathbf{w} / \mathbf{c}$ \\
\hline 1 & 1,050 & 0,060 & 0,110 & 0,075 & 0,194 \\
\hline \multicolumn{6}{|c|}{ Mixture - 16 $(H T 4+V 2)$} \\
\hline Cement & Sand & Metakaolin & Silica Fume & Additive SP & $\bar{w} \mathbf{w} / \mathbf{c}$ \\
\hline 1 & 1,050 & 0,050 & 0,100 & 0,065 & 0,194 \\
\hline \multicolumn{6}{|c|}{ Mixture - $17(H T 4+V 2)$} \\
\hline Cement & Sand & Metakaolin & Silica Fume & Additive SP & $\mathbf{w} / \mathbf{c}$ \\
\hline 1 & 1,050 & 0,050 & 0,080 & 0,060 & 0,184 \\
\hline
\end{tabular}

Source: Authors.

Mixture 13 incorporated a content of $1 \%$ of metallic fibers, according to the manufacturer's technical sheet, by weight, being the only one with the conditioning of fibers for this stage of laboratory refinement.

From the 2 curing conditions adopted in the first stage, 4 types of treatment were used, subjecting the specimens to random curing conditions to ascertain the existence of changes in the results at 7 and 14 days, as well as the progressions. In Heat Treatment 1 (HT1), the pre-cure time was 72 hours, with an isotherm of 16 hours at $75^{\circ} \mathrm{C}$, and a total heating time of 20 hours. In Heat Treatment 2 (HT2), the pre-cure time was 30 hours, with an isotherm of 80 hours at a temperature of $65^{\circ} \mathrm{C}$, and 
a total heating time of 84 hours. In Heat Treatment 3 (HT3), the pre-cure time was 30 hours, with an isotherm of 40 hours at a temperature of $60^{\circ} \mathrm{C}$, and a total heating time of 44 hours. In Heat Treatment 4 (HT4), the pre-cure time was 30 hours, with an isotherm of 32 hours at a temperature of $60^{\circ} \mathrm{C}$, and a total heating time of 36 hours. Trace 11 did not receive heat treatment.

As with the first 10 strokes, the density conditions used were the same, with condition of Vibration 1 (V1) consisting of dividing the procedure into 2 layers with 30 seconds of vibration, and condition of Vibration 2 (V2) dividing into 3 layers with 30 seconds of vibration, with the exception of Trace 11, which did not receive mechanical densification, depending only on its self-densification.

\subsubsection{Manufacturing Process}

Initially, the raw materials were separated and weighed according to each mix executed in the laboratory, involving cement, sand, metakaolin and silica fume, which were later homogenized in a plastic bag, ensuring the correct uniformity and distribution of the powders, as well such as water and additive, weighed with the aid of a beaker and beaker, respectively, and then unified in a single liquid (Figure 1).

Figure 1 - Separation of raw materials (a), homogenization of powders (b), and liquids (c).
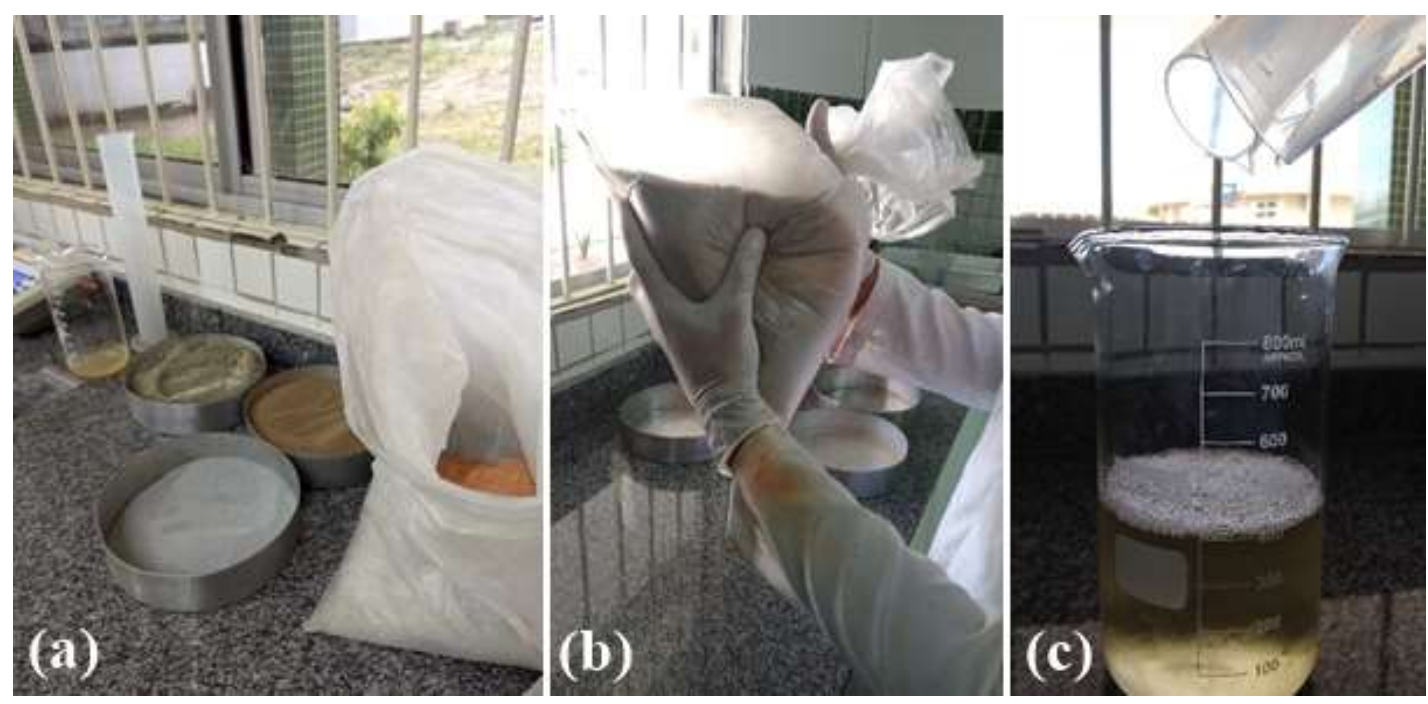

Souce: Authors.

It is worth mentioning that the water was only removed from the refrigeration environment at the time of mixing in the vat, so that the temperature of the vat did not increase, and the heat of hydration released by the cement was higher, compromising the quantity of the w/c ratio. With the aid of an adapted mortar (planetary mixer), half of the dry material was added, and little by little, the liquid was placed to start the homogenization process in $2 / 3$ of the total water and additive, performing previous homogenization manual (Figure 2). 
Figure 2 - Packaging of powders in the bowl (a), and manual homogenization (b).

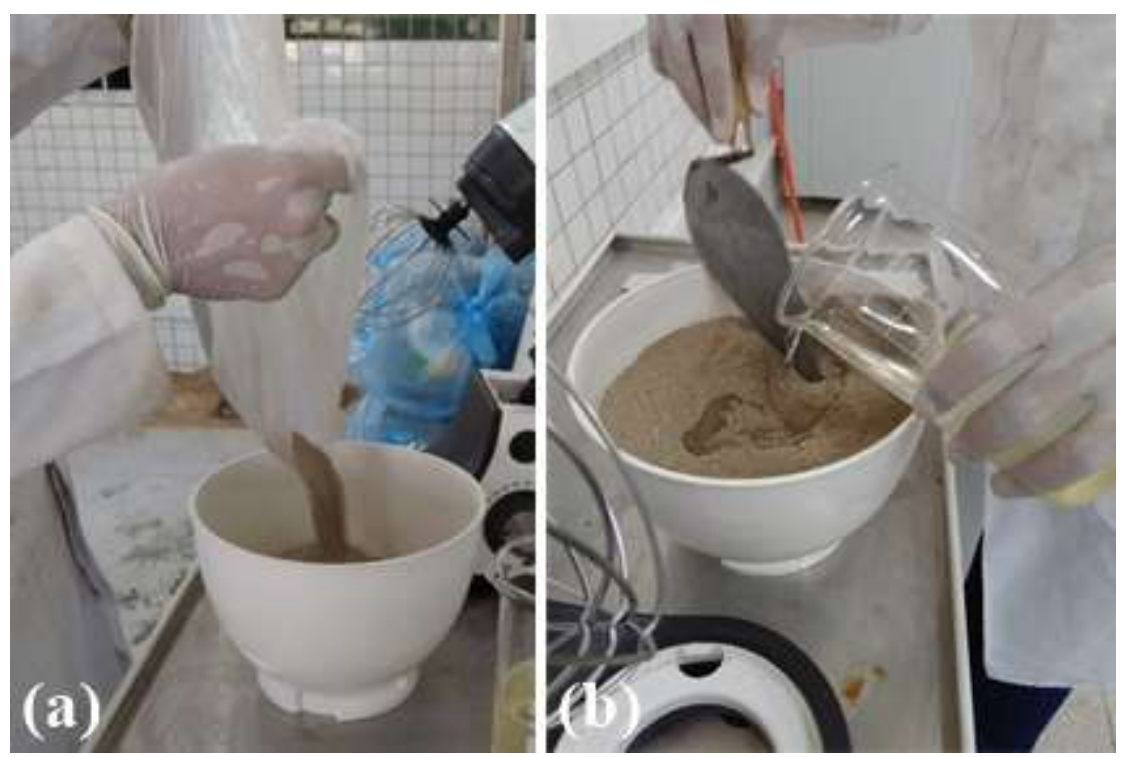

Source: Authors.

Right after the initial mixing with the help of a spatula, to better incorporate the materials, it was submitted to the mortar to give better efficiency in the mixture, and little by little the dry material was added, interspersed with the liquid, until the end of the entire procedure, lasting about 15 at 20 minutes, and then for another 5 minutes the material was subjected to the maximum speed of the mortar (Figure 3).

Figure 3 - Mechanical homogenization with intercalated addition of powders (a), and fabricated concrete (b).

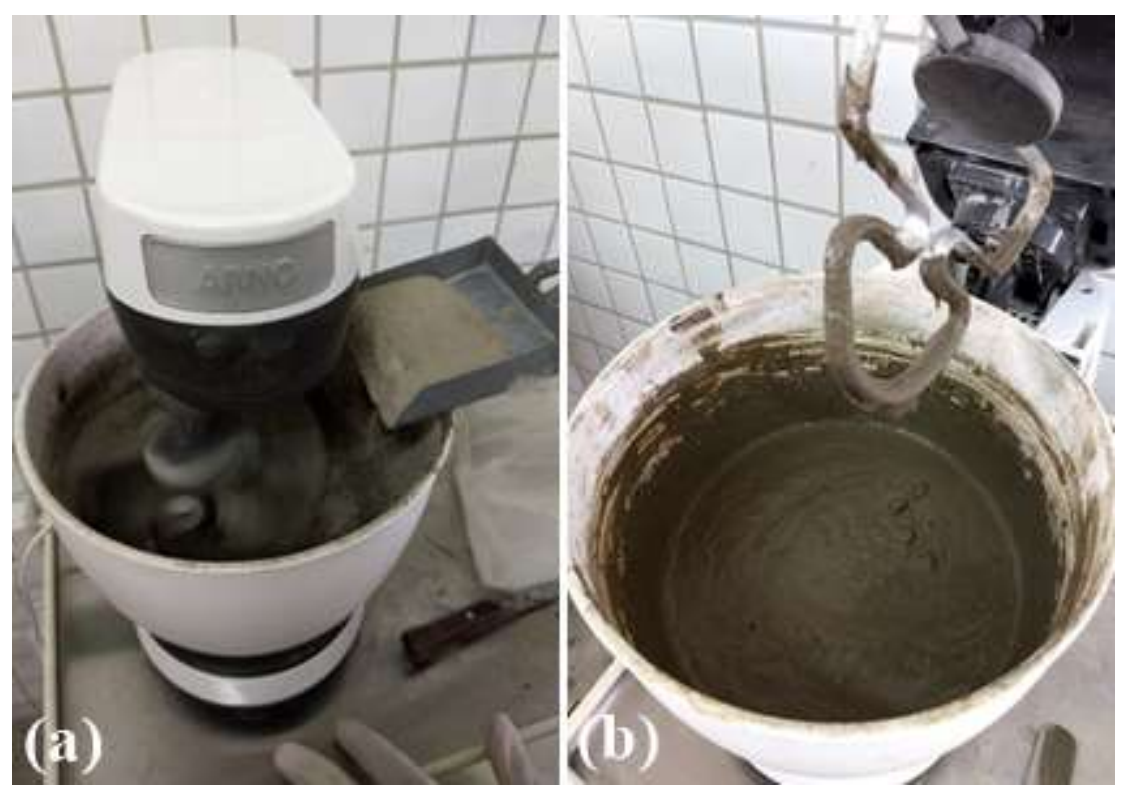

Source: Authors.

The molding step was constituted, for the manufacture of prototypes, through the densification with portable immersion vibrator VIBROMAK Model VBP-2512 with vibrations from 10,500 to 12,500 vpm and 25mm needle diameter, respecting the vibration conditions imposed in the planning of dosage, used in order to provide the best packaging of the mixture and minimization of the pores incorporated in the internal surface of the mold, adopting cylindrical molds of 
dimension 5x10cm (Figure 4).

Figure 4 - Molding procedure (a), and densification (b).

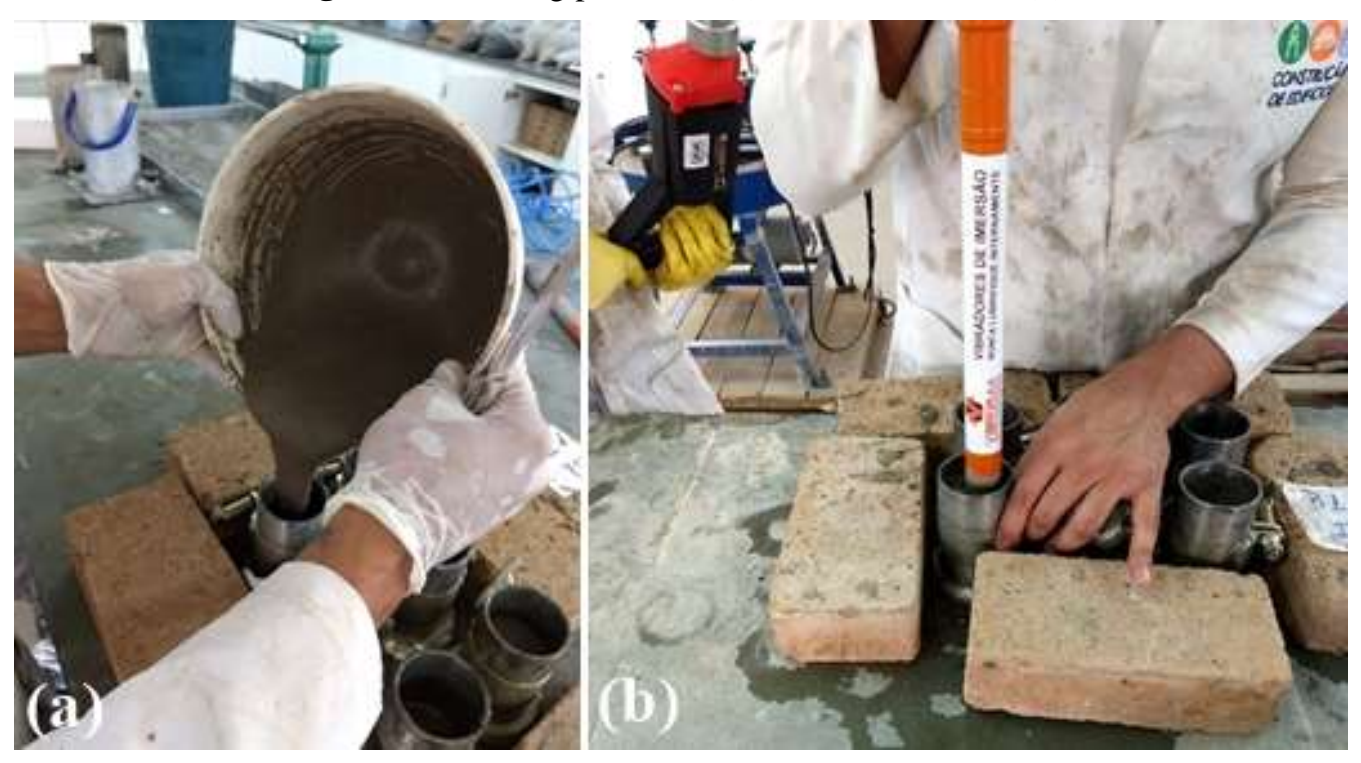

Source: Authors.

The fact that molds of this dimension are used constitutes, in addition to reducing the consumption of raw materials, a higher yield during the compressive strength test, as well as less necessary loading (press power) for ruptures of the specimens. After completing the thickening process, they were covered with plastic film and reserved until they were demolded within 24 hours (Figure 5).

Figure 5 - Initial curing of the specimens, at room temperature, covered with plastic film.

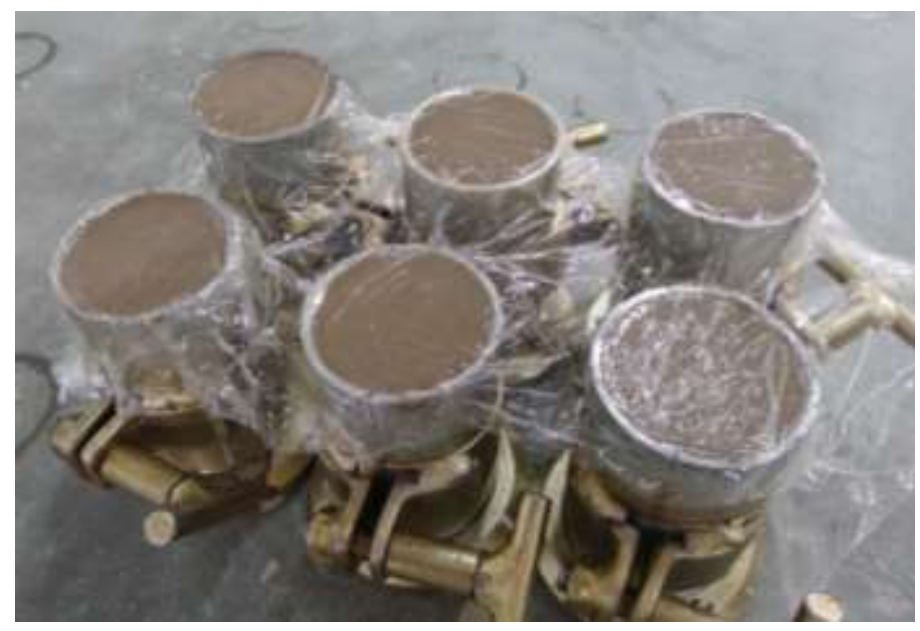

Source: Authors.

After deformation, they were immersed in the beakers of the heat treatment at $25^{\circ} \mathrm{C}$, until they were directed to the thermal curing process in an electric oven SOLAB Model SL-100 with a power of 3,000W and forced air circulation, respecting the conditions curing requirements imposed on dosage planning (Figure 6). It is worth mentioning that the water did not evaporate to the point that the prototypes were not fully submerged at the end of the determined time, taking this care through preliminary tests to check the water level after the official procedure. 
Figure 6 - Samples previously immersed (a), and beakers in an oven for heat treatment (b).
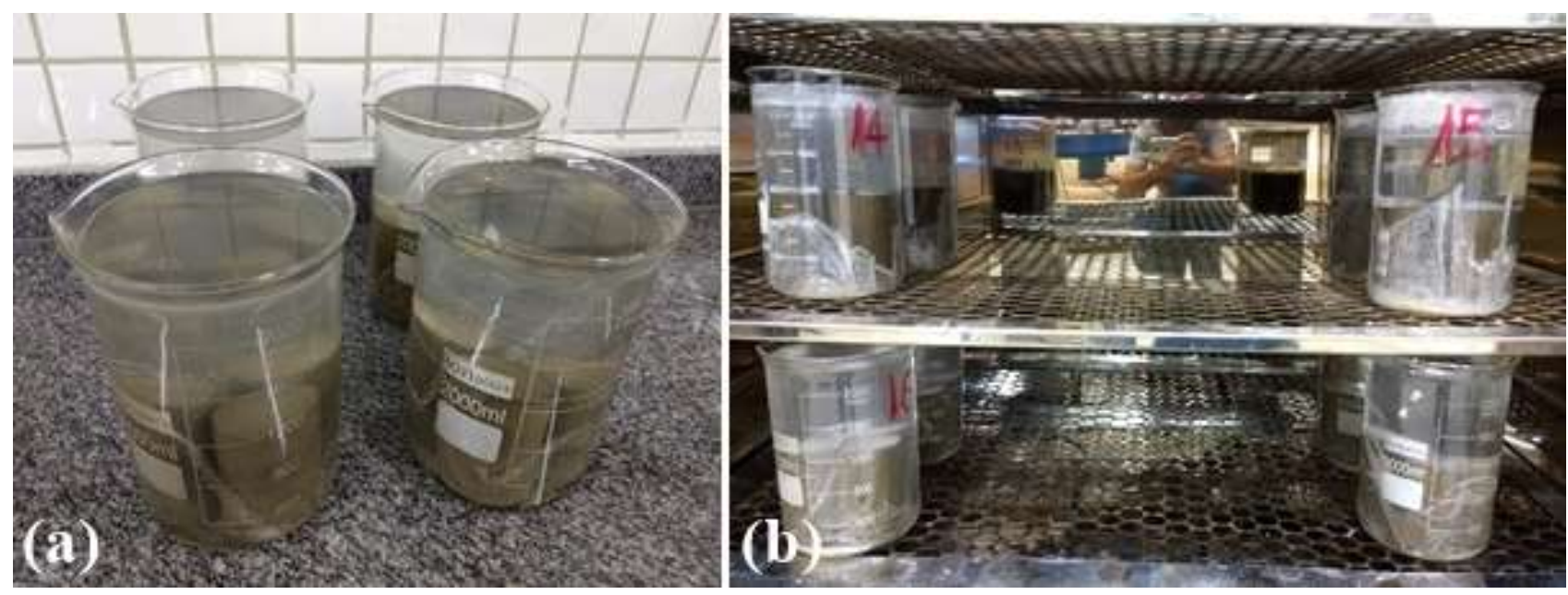

Source: Authors.

After each isotherm period, the beakers were removed from the oven to return to room temperature, then the specimens were removed and stored in a hydrated lime saturated tank (Figure 7), to perform the compression resistance test. axial at 7 and 14 days, according to ABNT NBR 5739:2007.

Figure 7 - Specimens in a tank saturated with hydrated lime.

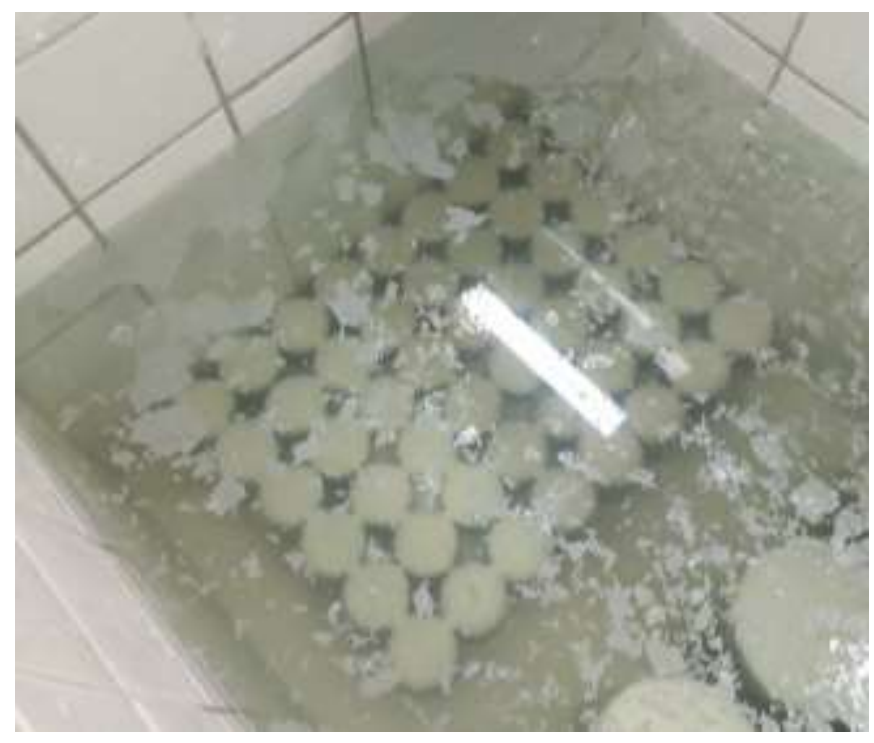

Source: Authors.

The standard recommends that, for the test, the loading be applied perpendicular to the cylindrical specimen, with a controlled breaking load speed of $0.45( \pm 0.15) \mathrm{MPa} / \mathrm{s}$, constant throughout the test. A MATEST electro-hydraulic press with 3 hp of power and capacity for 100 tons was used, equipment belonging to the Construction Materials Laboratory of the Federal Institute of Paraíba - Campina Grande Campus (Figure 8). 
Figure 8 - Press used in the mechanical resistivity test.

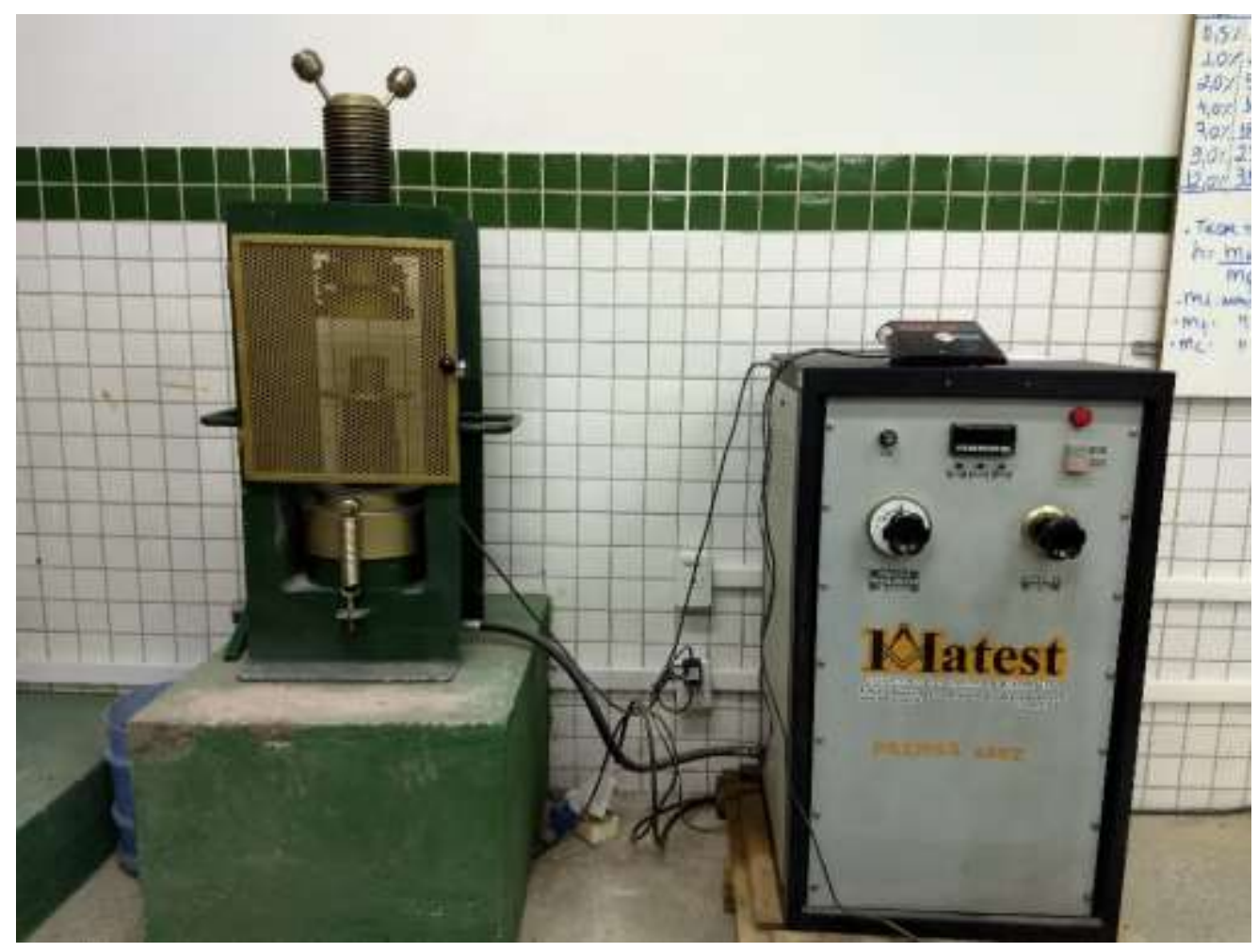

Source: Authors.

For calculation purposes, Equation 1 suggested by the standard was used, correcting, when necessary, the height/diameter ratio of the specimen to the maximum applied force.

$$
f_{c}=\frac{4 F}{\pi \cdot D^{2}}
$$

Equation (1)

\begin{abstract}
Where,
$\mathrm{f}_{\mathrm{c}}=$ Compressive strength $(\mathrm{MPa})$;

$\mathrm{F}=$ Maximum force achieved (N);

$\mathrm{D}=$ Diameter of specimen $\left(\mathrm{mm}^{2}\right)$.
\end{abstract}

\title{
3. Results and Discussion
}

\subsection{First Step}

By means of the first compositions created, Table 4 below shows the means, of three specimens tested for each mix, of the results of resistance to axial compression for the ages of 7 and 14 days. Figure 9 shows the behavior of the strokes as to the resistance by the age of rupture, obtaining a global parameter of how the idealized strokes behaved for the beginning of this laboratory study. 
Table 4 - Resistance to axial compression of the first stage mixtures.

\begin{tabular}{c|c|c}
\hline \multirow{2}{*}{ Mixtures } & \multicolumn{2}{|c}{ Ages } \\
\cline { 2 - 3 } & $\mathbf{7}$ ages & $\mathbf{1 4}$ ages \\
\hline $\mathbf{T}-\mathbf{1}$ & $80.052 \mathrm{MPa}$ & $79.777 \mathrm{MPa}$ \\
\hline $\mathbf{T}-\mathbf{2}$ & $103.638 \mathrm{MPa}$ & $98.691 \mathrm{MPa}$ \\
\hline $\mathbf{T}-\mathbf{3}$ & $112.782 \mathrm{MPa}$ & $118.529 \mathrm{MPa}$ \\
\hline $\mathbf{T}-\mathbf{4}$ & $108.435 \mathrm{MPa}$ & $109.218 \mathrm{MPa}$ \\
\hline $\mathbf{T}-\mathbf{5}$ & $126.524 \mathrm{MPa}$ & $129.198 \mathrm{MPa}$ \\
\hline $\mathbf{T}-\mathbf{6}$ & $118.904 \mathrm{MPa}$ & $115.656 \mathrm{MPa}$ \\
\hline $\mathbf{T}-\mathbf{7}$ & $80.318 \mathrm{MPa}$ & $81.751 \mathrm{MPa}$ \\
\hline $\mathbf{T}-\mathbf{8}$ & $99.74 \mathrm{MPa}$ & $116.93 \mathrm{MPa}$ \\
\hline $\mathbf{T}-\mathbf{9}$ & $116.181 \mathrm{MPa}$ & $119.204 \mathrm{MPa}$ \\
\hline $\mathbf{T}-\mathbf{1 0}$ & $111.25 \mathrm{MPa}$ & $126.575 \mathrm{MPa}$ \\
\hline
\end{tabular}

Source: Authors.

It is noteworthy that for all tests performed, the resistances obtained reached relatively reasonable values, interpreting that the formulations created for this special concrete border resistances between HPC and UHPC.

Comparing the results obtained with the concrete of reactive powders developed by Vanderlei (2004), it was observed that for the age of 7 days, 6 of the 10 features developed exceeded the mark reached by the author of 105.65 MPa in a reference feature without the addition of metallic fibers. In contrast, the results at 14 days for all strokes did not progress above $10 \%$ of the resistance, reaching a maximum limit of almost $130 \mathrm{MPa}$ for the best trace, with the author reaching the mark of approximately $160 \mathrm{MPa}$. It was noted that this non-progression is possibly associated with the high content of mineral admixtures (metakaolin and silica fume) in relation to cement, making it impossible to increase compressive strengths at older ages, regardless of the density method and type of thermal cure adopted.

Figure 9 - Characteristic breakage curves according to age.

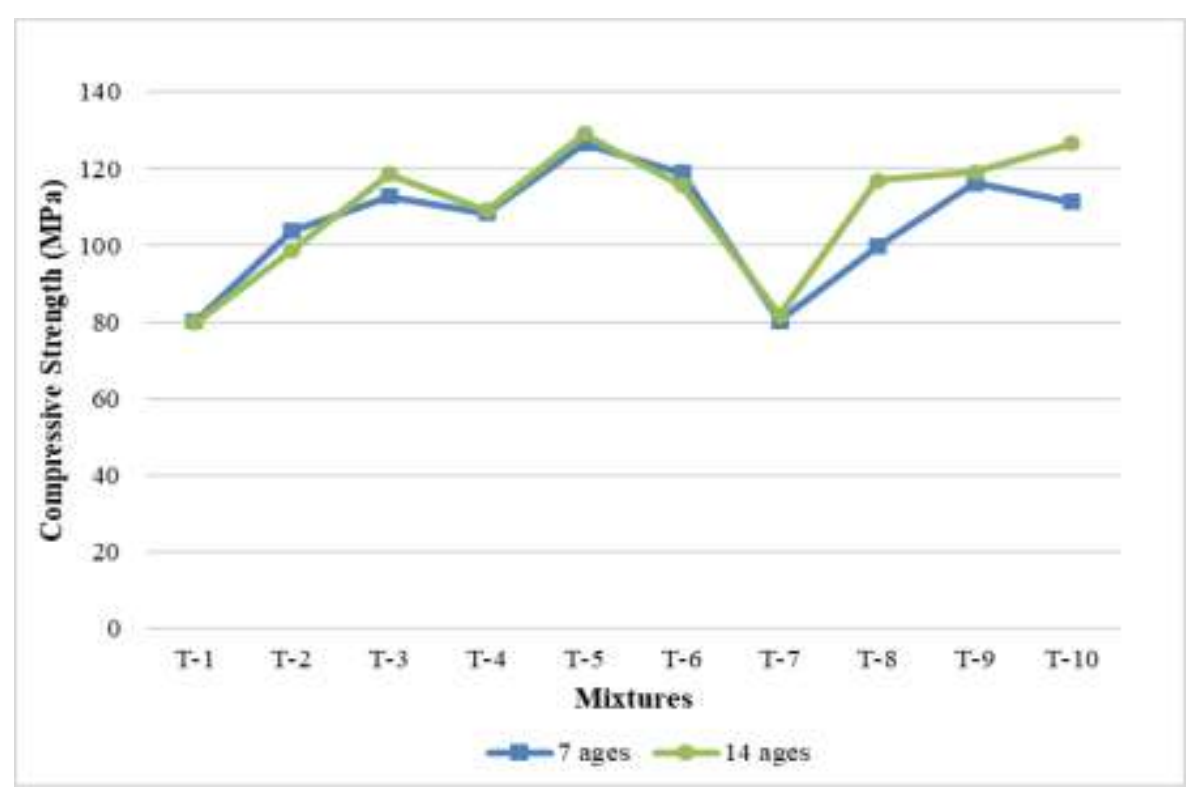

Source: Authors. 
Mineral admixtures also have an action of fundamental importance in order to achieve more relevant progressions, and a probable change in the quantity of admixtures can lead to better results in tests of resistance to axial compression (Figure $10)$.

Figure 10 - Visual presentation of specimens, absent of fibers, broken in mechanical test.
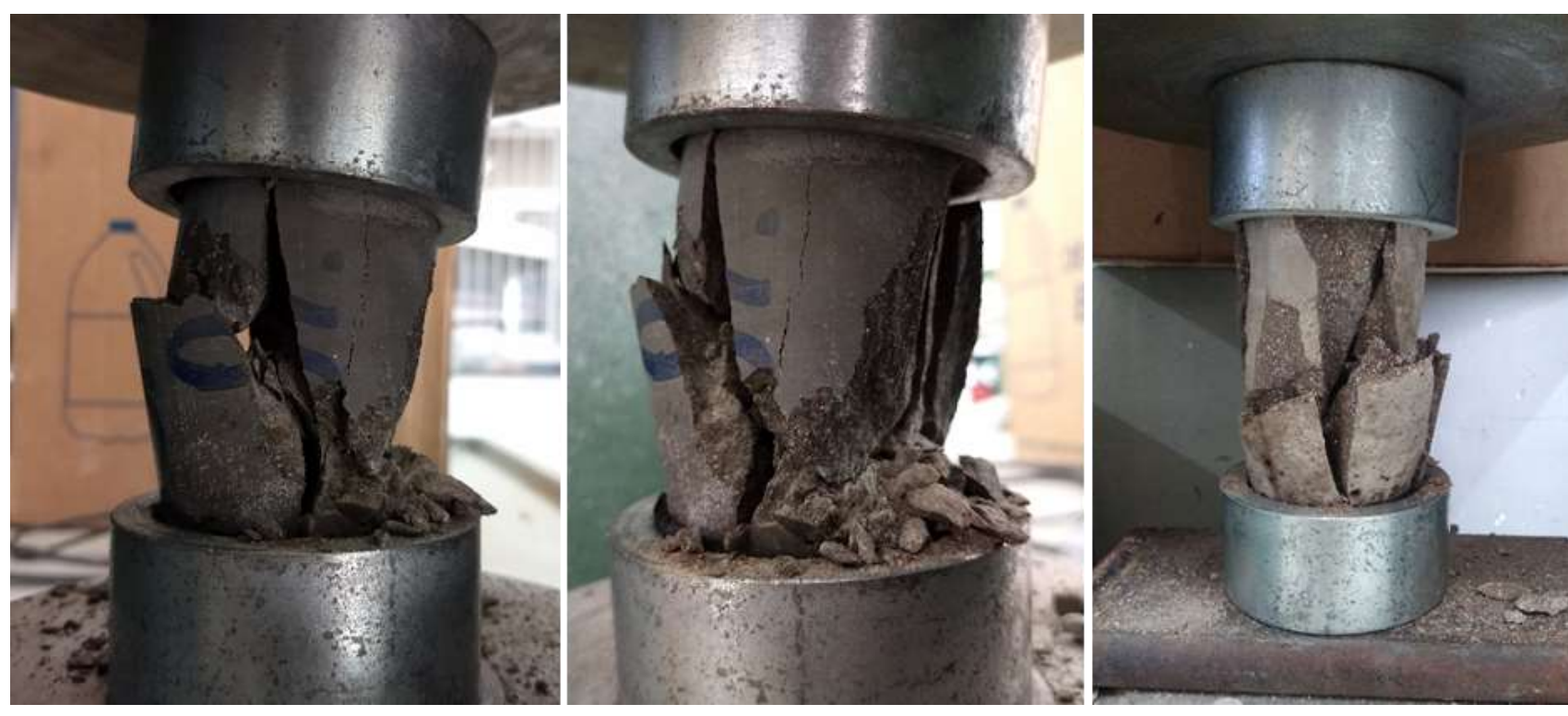

Source: Authors.

The w/c ratio that underwent some changes according to the type of cure and vibration, and also due to the number of admixtures that were used, caused better results for the two lowest values used (dashes T-5 and T-10). What distinguishes the T-5 trait from the T-10 trait is precisely the tiny difference in the quantities of mineral admixtures and additives: T-5 has 0.02 of its mass ratio less than the T-10 trait for metakaolin and silica fume, and the superplasticizer the difference is even greater: 0.05 .

This small difference exemplifies the potential for increased mechanical performance, and the composite is responsible for producing a better hydration reaction so that the pores become increasingly dense, minimizing the amount of defects and producing a better packaged matrix, reducing the energy cost with time excessive thermal curing and better balance in terms of reducing the use of materials used in the manufacture of concrete. Thus, the T-5 mix is the best developed within the methodology that covers the UHPC classes involved, showing the best results in the 7 and 14 day marks.

\subsection{Second Step}

Weighing each type of cure and densification introjected to the chosen features, Table 5 shows the averages obtained from the breaks made for the ages of 7 and 14 days.

Then, Figure 11 shows an overall sampling of the behavior of the strokes in view of the decrease in the a / c factor and mineral admixtures, improvement in the type of density and in the discernment regarding the choice of intervals for each type of heat treatment conditioned to the prototypes. 
Table 5 - Resistance to axial compression of the traces of the second stage.

\begin{tabular}{c|c|c}
\hline \multirow{2}{*}{ Mixtures } & \multicolumn{2}{|c}{ Ages } \\
\cline { 2 - 3 } & $\mathbf{7}$ ages & $\mathbf{1 4}$ ages \\
\hline $\mathbf{T}-\mathbf{1 1}$ & $71.54 \mathrm{MPa}$ & $88.18 \mathrm{MPa}$ \\
\hline $\mathbf{T}-\mathbf{1 2}$ & $106.203 \mathrm{MPa}$ & $114.482 \mathrm{MPa}$ \\
\hline $\mathbf{T}-\mathbf{1 3}$ & $123.951 \mathrm{MPa}$ & $141.94 \mathrm{MPa}$ \\
\hline $\mathbf{T}-\mathbf{1 4}$ & $152.959 \mathrm{MPa}$ & $159.38 \mathrm{MPa}$ \\
\hline $\mathbf{T}-\mathbf{1 5}$ & $159.18 \mathrm{MPa}$ & $169.399 \mathrm{MPa}$ \\
\hline $\mathbf{T}-\mathbf{1 6}$ & $160.954 \mathrm{MPa}$ & $156.523 \mathrm{MPa}$ \\
\hline $\mathbf{T}-\mathbf{1 7}$ & $161.97 \mathrm{MPa}$ & $150.91 \mathrm{MPa}$ \\
\hline
\end{tabular}

Source: Authors.

It was observed that, for the results obtained, the best trait with satisfactory results of high resistance was the T-15. Comparing with the data resulting from the research by Vanderlei (2004), which for 7 days reached 105.65 MPa, there was an increase of more than $50 \%$ in compressive strength. With the exception of the T-11 mix, which did not receive heat treatment or thickening, adapting to the mixture when in the fresh state, all other mixtures surpassed the mark of Vanderlei (2004) at 7 days.

The heat treatment in which the prototypes were submitted accelerated the production process of the hydrates that make up the cementitious matrix of the material, and it is possible to observe that the isotherms of the T-2, T-4, T-5, T-6 and T-7 mixtures, although there are differences in time and temperature, they did not vehemently alter the progression from 7 to 14 days, noting also a similar advance for the T-3 trait, which even receiving an 84-hour isotherm, does not provided a differentiated result from the others, inferring that there is an ideal period in obtaining satisfactory results with less energy expenditure.

Figure 11 - Variation of compressive strength depending on composition and curing time.

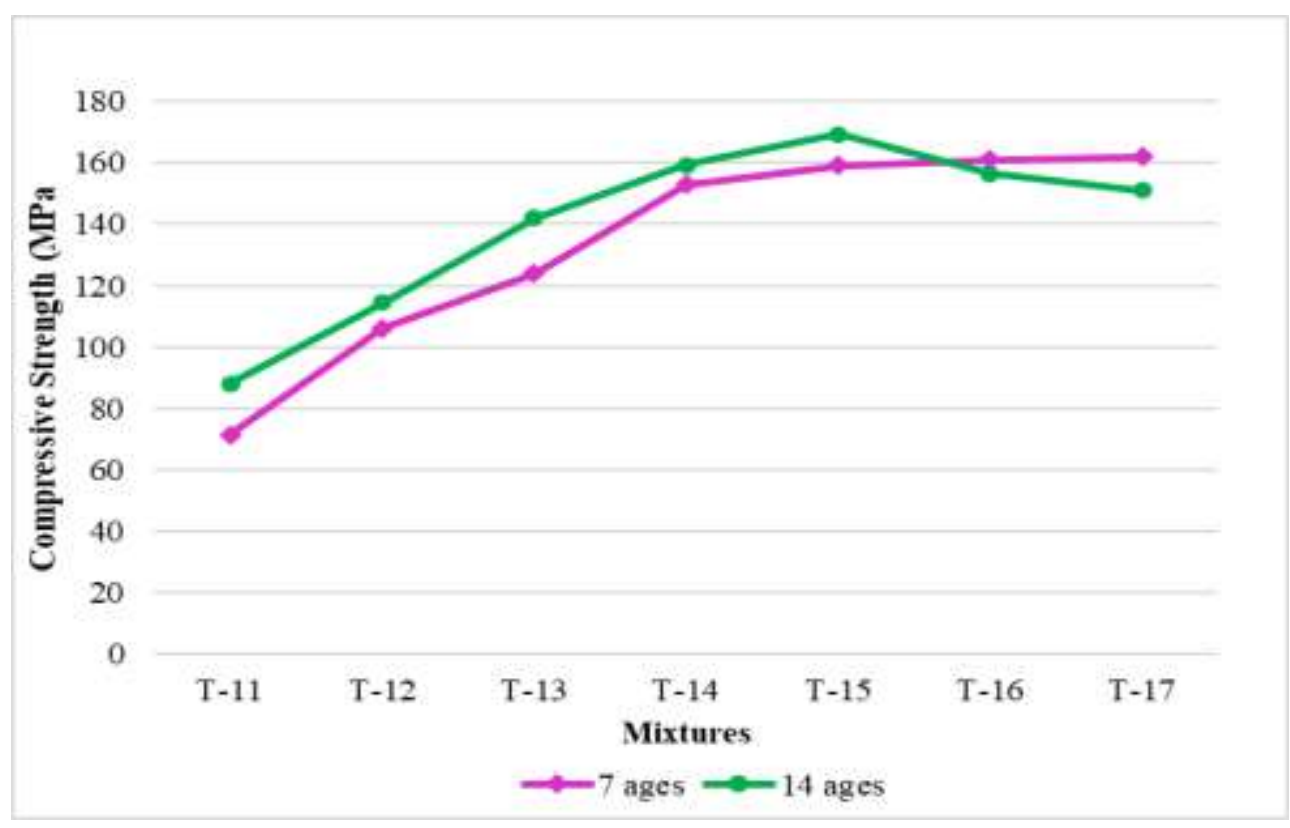

Source: Authors. 
The mixtures T-16 and T-17 obtained better results than the T-15 at the age of 7 days, but they were not considered to be better for this study because there was no progression of the values at 14 days of age, besides not having overcome the Vanderlei (2004) mark at that age, which was 159.60 MPa, and the T-15 mix showed 169.399 MPa of resistance, exceeding the mark reached by the author by $6.13 \%$. The T-11 mixture again did not reach the mark of the confronted author.

The influence of microfibers for the T-13 mix corroborated better progression, among all mixtures, at 14 days of age, since the folds at the ends of each fiber favor an internal anchorage that, from Young's high modulus, absorb and they distribute the load received during the resistance test more evenly, associated with an increase in the ductility and toughness of the material, having been demonstrated through the $14.5 \%$ increase in mechanical resistivity (Figure 12).

The decline in progressions in mechanical performance is attributed to the T-16 and T-17 mixtures due to the drastic reduction of the w/c ratio, and it can be interpreted that there was not the correct and total hydration of all Portland cement particles. that make up the mixture, reducing the packaging of the composite by creating zones absent from crystalline phases arising from these chemical reactions. The non-production of the hydrated compounds favors that part of the mineral admixtures remain inactive, not filling the voids left by the water, after the curing process, due to the low production of C-S-H.

Figure 12 - Specimens, with steel fibers, fractured in a compressive strength test.
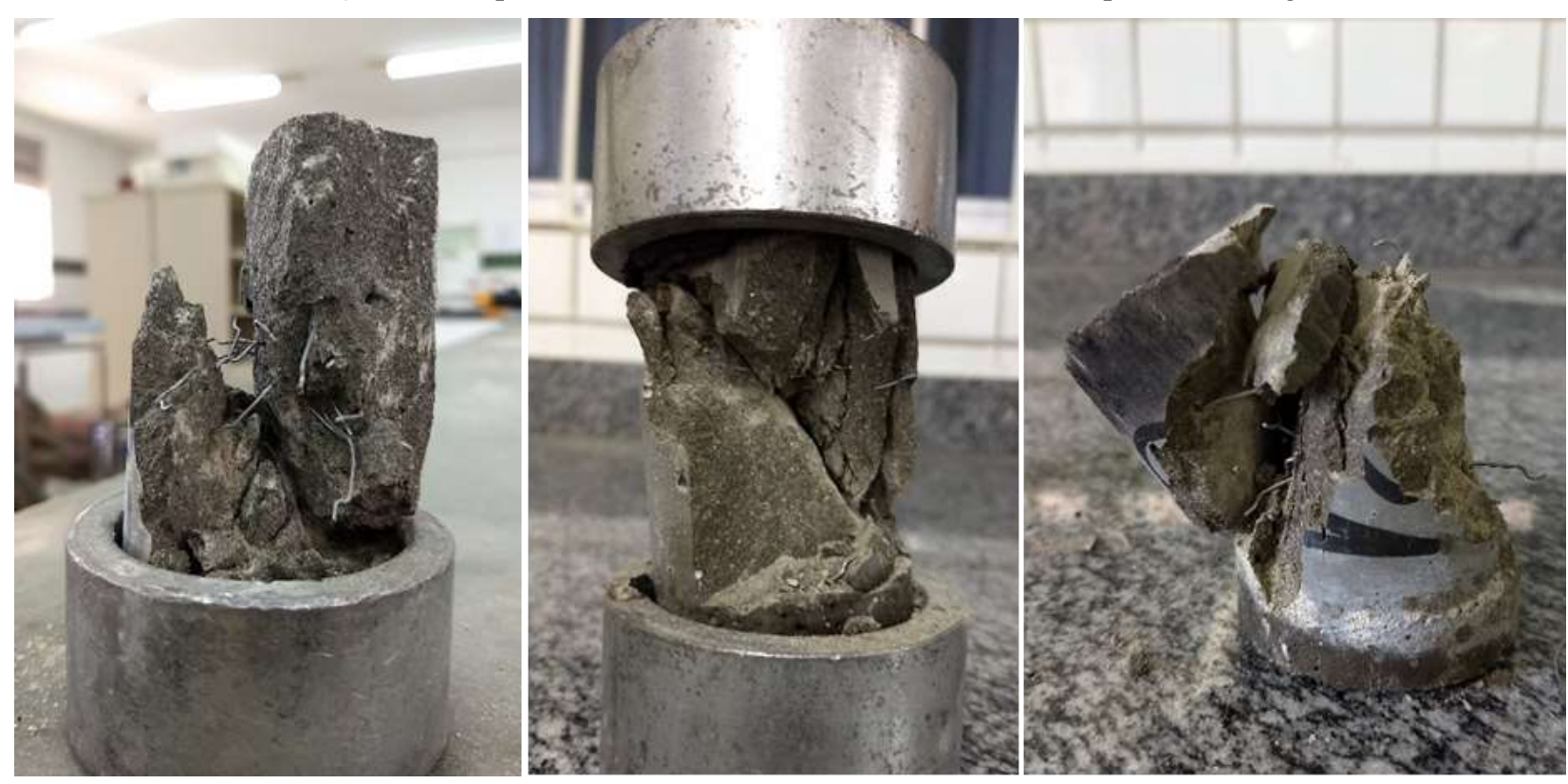

Source: Authors.

The small difference for the results obtained in the progressions of the T-14 and T-15 mixtures, at 7 and 14 days, is associated with the fact that 2 mineral admixtures are used, where the faster advance of reactions in the first age due to the synergistic work of metakaolin with silica fume, which for the second age analyzed, progressed in percentages of $4.19 \%$ and $6.41 \%$, respectively, advancing more slowly due to the reactions with greater intensity having occurred before, during, and after the thermal curing process of the material in fractions of hours. Comparing with Vanderlei (2004), the progression at 14 days advanced more than $50 \%$ compared to 7 days, since he used only silica fume as a mineral admixture.

\section{Conclusion}

Through laboratory tests, which adopted a methodology used in the experimental manufacture of concrete from reactive powders for the production of concrete of the same strength class as UHPC, with more than one mineral admixture 
inherent in pozzolanic potential, it is concluded that, for the first processing stage of the compositions, the measured axial compression resistance ranges corroborate with the improvement in the quantity of the traces, highlighting the metakaolin, the silica fume and the superplasticizer, great allies in obtaining ultra high performance performances in matrix composites when cemented in a coherent manner.

The procedure used for densification and heat treatment ensures that the features developed promote better mechanical behavior without considerable modification in the density mode (increase in the number of layers), or in the isotherm time (increase in residence time in the greenhouse) and their respective temperatures. The w/c ratio denotes good material yield for the 10 mixtures tested, requiring a modification when the superplasticizer is modified in the mixture, which was planned for the second stage.

The T-5 was the one with the best results regarding the highest value obtained during the test, for both ages of study, with $126.524 \mathrm{MPa}$ at 7 days and $129.198 \mathrm{MPa}$ at 14 days. Note that it has the lowest w/c ratio of all 10 features with 0.244 , the same ratio as T-10, but because T-10 has a higher quantity of mineral admixtures, even if minimal, it is ratified that when reducing the respective quantities, there is a tendency of resistance to increase, since the consumption of portlandite is balanced and the mixture is better packaged.

The mixtures T-1 and T-7, which obtained similar strengths in the two ages studied, even with different curing and densification conditions used in the manufacturing process, present two different explanations: for T-1, the resistances were concentrated in the $80 \mathrm{MPa}$ range due to the high percentage of mineral admixtures used, exceeding the ideal amount for $\mathrm{CH}$ consumption to be controlled, improving packaging, and due to the high percentage $\mathrm{CH}$ was completely consumed, leaving a huge mass of additions in the mixture, which they may have functioned positively as an inert material for filling pores or negatively disrupting the packaging of the mixture, which required w/c ratio also in high quantity to confer permissible densification properties; for T-7, the effect was reversed, because even with the percentage of mineral admixtures substantially lower than T-1, similar to T-5 (best feature of the first stage), which produced a consumption of $\mathrm{CH}$ close to an ideal packaging, the w/c ratio was higher than necessary, resulting in pores inside the material, reducing the compressive strength of the material because there is a possible continuity of the porous network, that is, interconnection of pores that weaken the hydrated matrix of the UHPC.

The features developed for the second stage of this study, seeking to improve the values of mineral admixtures, additive content and w/c ratio, demonstrated the expected improvement. The T-15 mix was the one that best behaved due to the $6.41 \%$ progression, at 14 days of being effective with a maximum peak of $169.399 \mathrm{MPa}$, a behavior not noticed for the T16 and T-17 mixtures, which obtained 156.523 MPa and 150.910 MPa respectively, even with values higher than T-15 at 7 days of age.

When comparing the T-14 with the T-15, the progressions are similar (4.19\% and $6.41 \%)$, however the higher values of T-15 are corroborated due to the lower consumption of mineral admixtures and decreased w/c ratio. It is possible to affirm that, from the results of the T-11 mix, the densification and heat treatment procedures are necessary to guarantee the achievement of satisfactory results, something already observed in the results of the first stage of this study.

The use of metallic microfibers confirms the improvement of the properties of the material in the hardened state for older ages, with the T-13 mixture, despite having lower resistance, it presents the greatest progression from 7 to 14 days with an increase of $14.5 \%$, demonstrating that $1 \%$ addition of steel fibers, already positively improves the properties of RPC.

The synergy of mineral admixtures accelerates the production process of this type of concrete for precast articles, as well as a faster application by obtaining more than $80 \%$ of the final strength at 7 days of age due to the fast consumption of $\mathrm{CH}$, with the rest the percentage of additions, which remain inert, acting on the refinement of the porous network.

It is concluded that the sensible use of the ideal thermal curing time between 35 and 40 hours at $60^{\circ} \mathrm{C}$, guarantees a 
potential advance in the construction stages of a work that depends heavily on this material, being also possible to observe that, the smaller the pre-curing time used, the more effective it is to cure the specimens in a water bath, as the microstructure is not yet fully consolidated right after the first hours of preparation, with emphasis on the production of C-S-H.

\section{Acknowledgments}

To CNPq for granting the scholarship, in PIBITI modality, to the first author. To IFPB - Campus Campina Grande for the laboratory structure. To companies: Elizabeth Cimentos, BASF S.A., Belgo Bekaert \& ArcellorMittal, Maia Macedo, and Tecnosil for donations of raw materials to carry out the study.

\section{References}

Andrade, T. C. C. S. (2015). Avaliação do tipo de cura nas propriedades de concretos de pós reativos. Dissertação de mestrado, Universidade Federal do Paraná, Curitiba, PR, Brasil.

Associação Brasileira de Normas Técnicas. ABNT NBR 5739 - Concreto - Ensaio de compressão de corpos-de-prova cilíndricos. Rio de Janeiro, 2007.

Biz, C. E. (2001). Concreto de pós reativos. Dissertação de mestrado, Universidade Estadual de Campinas, Campinas, SP, Brasil.

Cunha Oliveira, J. V., Chagas, L. S. V. B., Meira, F. F. D. A., Carneiro, A. M. P., \& Melo Neto, A. A. (2020). Study of the potential of adhesion to the substrate of masonry and tensile in the flexion in mortars of coating with gray of the sewage sludge. Materials Science Forum, 1012, $256-261$. https://doi.org/10.4028/www.scientific.net/MSF.1012.256

Dixit, A., Du, H., \& Pang, S. D. (2020). Marine clay in ultra-high-performance concrete for filler substitution. Construction and Building Materials, 263, 120250. https://doi.org/10.1016/j.conbuildmat.2020.120250

Figueiredo, A. D. (2011). Concreto reforçado com fibras. Tese de livre docência, Universidade de São Paulo, São Paulo, SP, Brasil.

Kang, S. H., \& Hong, S. G., Moon, J. (2019). The use of rice husk ash as reactive filler in ultra-high performance concrete. Cement and Concrete Research, 115, 389-400. https://doi.org/10.1016/j.cemconres.2018.09.004

Liu, T., Wei, H., Zou, D., Zhou, A., \& Jian, H. (2020). Utilization of waste cathode ray tube funnel glass for ultra-high performance concrete. Journal of Cleaner Production, 249, 119333. https://doi.org/10.1016/j.jclepro.2019.119333

Mallmann, P. F. (2013). Concreto de pós reativos: adição de nanosílica. Monografia de graduação, Universidade Federal do Rio Grande do Sul, Porto Alegre, RS, Brasil.

Oliveira, J. V. C. (2020). State of the art of the development of sustainable concrete for applications in conventional structures. Research, Society and Development, 9 (11), 1-19. http://dx.doi.org/10.33448/rsd-v9i11.10272

Pelisser, F., Gleize, P. J. P., \& Mikowski, A. (2009). Propriedades nanomecânicas do silicato de cálcio hidratado de síntese. Ambiente Construído, 9 (42), 129139. http://dx.doi.org/10.1590/s1678-86212009000400523

Perim, J. R. (2013). Influência do metacaulim na durabilidade de concretos usuais de mercado sujeitos à carbonatação acelerada. Dissertação de mestrado, Universidade Federal de Goiás, Goiânia, GO, Brasil.

Richard, P., \& Cheyrezy, M. (1995). Composition of reactive powder concretes. Cement and Concrete Research, 25 (7), 1501-1511. https://doi.org/10.1016/0008-8846(95)00144-2

Rigo, L. A. (2016). Estudo da sinergia entre nano sílica e micro sílica em argamassas para aplicação em concretos como proposta de melhoria de desempenho. Monografia de graduação, Universidade Tecnológica Federal do Paraná, Pato Branco, PR, Brasil.

Seitenfuss, A. B., Lima, M. S., \& Silva, A. W. (2014). Estudo de dosagem de concreto de alto desempenho. In: $21^{\circ}$ CBECIMAT, Cuiabá, Mato Grosso, Brasil, 2014. <https://bit.ly/2MXMIGx>.

Sohail, M. G., Kahraman, R., Nuaimi, N. A., Gencturk, B., \& Alnahhal, W. (2021). Durability characteristics of high and ultra-high performance concretes. Journal of Building Engineering, 33, 101669. https://doi.org/10.1016/j.jobe.2020.101669

Tutikian, B. F., Isaia, G. C., \& Helene, P. (2011). Concreto de alto e ultra-alto desempenho. In: Isaia, G. C. (Org.). Concreto: Ciência e Tecnologia: IBRACON, 1238-1325.

Vanderlei, R. D. (2004). Análise experimental do concreto de pós reativos: dosagem e propriedades mecânicas. Tese de doutorado, Universidade de São Paulo, São Carlos, SP, Brasil. 